\title{
DET DANSKE EU-FORMANDSKAB PA DET POLITIMÆSSIGE OG STRAFFERETLIGE OMRÅDE
}

\author{
AF KOMMITTERET JAKOB SCHARF
}

\section{Indledning}

I perioden fra den 1. juli til den 31. december 2002 varetog Danmark formandskabet i EU, herunder på det politimæssige og strafferetlige område, hvor samarbejdet foregår på grundlag reglerne i afsnit VI i Traktaten om Den Europæiske Union.

Formandskabet indebar bl.a., at ca. 20 arbejdsgrupper, undergrupper, ekspertgrupper, komiteer og udvalg m.v. på det politimæssige og strafferetlige område, der assisterer Rådet vedrørende retlige og indre anliggender i dets sammensætning af EU-landenes justits- og indenrigsministre, blev ledet af danske formænd.

Under det danske formandskab blev der dagligt afholdt et eller flere møder i arbejdsgrupperne m.v. inden for det politimæssige og strafferetlige samarbejde, hvor de danske formænd blev bistået af et særligt formandskabssekretariat i Justitsministeriet, der ligeledes koordinerede formandskabets indsats, herunder særligt med henblik på det uformelle EU-justits- og indenrigsministermøde i København i september måned 2002 og de tre efterfølgende formelle rådsmøder om retlige og indre anliggende. Rådsmøder, som mundede ud i 49 nye vedtagelser i Rådet alene på det politimæssige og strafferetlige område samt politisk enighed i Rådet om en række yderligere forslag.

Udover de mange møder som led i Rådets arbejde blev der under det danske EU-formandskab afholdt flere konferencer og seminarer m.v. i Danmark med deltagelse af eksperter fra de øvrige EU-lande, ligesom der som led i EU's forbindelse med tredjelande blev afholdt såkaldte "trojka-møder" på ministerniveau med Rusland og Ukraine.

I det følgende gennemgås de væsentligste resultater af det danske EU-formandskab på det politimæssige og strafferetlige område.

\section{Generelt}

Rådet vedtog den 22. juli 2002 et rammeprogram for finansiering over Fallesskabets budget af aktiviteter som led $i$ det politimaessige og strafferetlige samarbejde (AGIS-programmet). ${ }^{2}$ Formålet med rammeprogrammet er at samle finansieringsprogrammerne inden for det politimæssige og strafferetlige samarbejde bl.a. med henblik på at sikre en bedre overordnet sammenhæng.

Programmet, der indføres for en 5-årig periode (1. januar 2003 - 31. december 2007) med mulighed for forlængelse og forvaltes af Kommissionen, tager sigte på at udvikle, gennemføre og evaluere EU-samarbejdet på det politimæssi- 
ge og strafferetlige område. Endvidere tager programmet sigte på at fremme og styrke oprettelsen af netværk, gensidigt samarbejde om generelle emner af fælles interesse for medlemsstaterne, udveksling og videreformidling af oplysninger og erfaringer, lokalt og regionalt samarbejde samt forbedring og tilpasning af den uddannelsesmæssige indsats og den videnskabelige og tekniske forskning. Endelig er formålet med programmet at fremme en styrkelse af medlemsstaternes samarbejde med kandidatlandene, andre tredjelande og relevante internationale og regionale organisationer.

Projekter med en maksimal varighed på to år, der gennemføres af offentlige eller private institutioner og organer, herunder erhvervssammenslutninger, ikkestatslige organisationer, foreninger, organisationer, uddannelsesinstitutter og de retshåndhævende myndigheder i medlemsstaterne og kandidatlandene, kan samfinansieres inden for rammerne af AGIS-programmet. Det er i øvrigt en betingelse for at modtage finansieringstilskud, at et projekt omfatter mindst tre medlemsstater eller to medlemsstater og et kandidatland. Tilskud fra AGIS-programmet må som udgangspunkt ikke overstige $70 \%$ af de samlede projektomkostninger.

\section{Politisamarbejde}

\section{Samarbejdet mellem nationale politimyndigheder m.v.}

Rådet vedtog den 28. november 2002 en afgørelse om oprettelse af et europaisk netvark til beskyttelse af fremtradende personer. ${ }^{3}$

Rådsafgørelsen indebærer, at der oprettes et europæisk netværk til beskyttelse af fremtrædende personer. Netværket består af nationale kontaktpunkter for de nationale polititjenester med ansvar for beskyttelse af fremtrædende personer. Kandidatlandene og Europol kan ligeledes udpege kontaktpunkter med henblik på deltagelse i netværket.

Netværket har til opgave at fremme udvekslingen af erfaringer samt generelle og tekniske oplysninger i forbindelse med beskyttelsen af fremtrædende personer, fastlæggelsen af fælles kriterier for udvælgelse og uddannelse af personale samt retningslinjer for den sikkerhedsmæssige håndtering af beskyttelsen af fremtrædende personer. Endvidere skal netværket fremme udvekslingen af forbindelsesofficerer. Endelig skal netværket fremme udvekslingen af operative oplysninger via kontaktpunkterne eller de relevante nationale myndigheder. Udvekslingen af oplysninger sker i overensstemmelse med national ret.

På rådsmødet (retlige og indre anliggender) den 19. december 2002 blev der opnået politisk enighed om en rådsafgørelse vedrørende falles udnyttelse af medlemsstaternes politi-forbindelsesofficerer i tredjelande og ved internationale organisationer. ${ }^{4}$

Rådsafgørelsen har til formål at styrke samarbejdet mellem medlemsstaterne i forbindelse med udsendelsen af politifolk, der fungerer som forbindelsesoffi- 
cerer i tredjelande og inden for rammerne af visse internationale organisationer.

Rådsafgørelsen indebærer, at der løbende udarbejdes fælles oversigter over medlemsstaternes forbindelsesofficerer, og at der etableres et tæt samarbejde mellem de politifolk, medlemsstaterne har udsendt som forbindelsesofficerer til samme tredjeland eller internationale organisation.

En forbindelsesofficer fra en medlemstat, der modtager oplysninger om grov kriminalitet af betydning for en anden medlemsstat, skal ifølge rådsafgørelsen drage omsorg for, at oplysningerne videregives til den relevante medlemsstat. Endvidere kan medlemsstater, der ikke har udsendt forbindelsesofficerer til et tredjeland eller en international organisation, anmode om bistand fra en anden medlemsstats forbindelsesofficerer på stedet. En tilsvarende adgang etableres for Europol med henblik på at anmode om bistand fra medlemsstaternes forbindelsesofficerer i tredjelande og ved internationale organisationer.

\section{Europol $^{5}$}

Rådet vedtog den 28. november 2002 en protokol om andring af Europol-konventionen. ${ }^{6}$ Samme dag blev protokollen undertegnet af medlemsstaterne.

Protokollen indebærer, at Europol får mulighed for at deltage i fælles efterforskningshold i en støttefunktion og inden for rammerne af Europols beføjelser på grundlag af Europol-konventionens øvrige bestemmelser.

Endvidere vil protokollen give Europol mulighed for at anmode medlemsstaterne om at indlede strafferetlig efterforskning i specifikke tilfælde. Medlemsstaterne vil dog ikke være forpligtede til at efterkomme en sådan anmodning.

Protokollen indebærer ligeledes, at Europol-ansatte ikke nyder immunitet i forhold til opgaver udført i embedes medfør som led i deltagelsen i en støttefunktion i et fælles efterforskningsholds aktiviteter, ligesom Europols ansvar for den skade, som ansatte måtte forvolde, udvides til at omfatte skade forvoldt under bistand til fælles efterforskningshold. Den medlemsstat, på hvis område skaden forvoldes, erstatter i første omgang sådan skade på samme måde som ved skader forvoldt af medlemsstatens egne ansatte, hvorefter Europol godtgør beløb udbetalt i skadeserstatning.

På rådsmødet (retlige og indre anliggender) den 19. december 2002 blev der opnået politisk enighed om yderligere en protokol med henblik på en revision af Europol-konventionen. ${ }^{7}$ Sigtet med protokollen, der forventes vedtaget i løbet af 2003, er at styrke og effektivisere det politimæssige samarbejde via Europol i lyset af de hidtidige erfaringer, siden Europol påbegyndte sit virke i 1999.

Protokollen indebærer, at Europol får kompetence til generelt at beskæftige sig med bekæmpelse af grov, international kriminalitet, hvis der er mistanke om, at der foreligger en kriminel struktur eller organisation, i det omfang to eller flere medlemsstater berøres af kriminaliteten, og de strafbare handlingers omfang, betydning og følger gør fælles handling fra medlemsstaternes side påkrævet. De relevante former for grov, international kriminalitet er opregnet i konventionen 
og i et bilag til konventionen, idet Rådet ved en rådsafgørelse kan beslutte at inddrage yderligere kriminalitetsformer. Prioriteterne for Europols virksomhed fastlægges i øvrigt af Rådet.

Herudover præciserer protokollen, at Europol kan fremme medlemsstaternes indbyrdes tekniske støtte i forbindelse med efterforskningen af strafbare handlinger, og at Europol udgør et fælles kontaktpunkt i forbindelse med samarbejdet med tredjelande og internationale organisationer om bekæmpelse af falskmøntneri i forhold til euroen.

Protokollen indebærer, at der i videre omfang kan etableres direkte samarbejde mellem Europol og kompetente nationale myndigheder, herunder i forbindelse med brugen af Europols informationssystem.

Med protokollen ændres en række af Europol-konventionens bestemmelser vedrørende Europols analysedatabaser og informationssystem samt databeskyttelsen i Europol-regi, ligesom Europol efter protokollen vil kunne fă adgang til at søge i eksterne informationssystemer, f.eks. Schengen-informationssystemet, i det omfang regelgrundlaget for det pågældende informationssystem tillader det.

Med henblik på at skabe øget åbenhed og styrke den demokratiske kontrol med Europol lægges der i protokollen op til, at Europols Styrelsesråd skal fastlægge bestemmelser om adgang til aktindsigt i Europols dokumenter for enhver borger eller juridisk person i medlemsstaterne. Desuden kan formanden for Rådet, eller dennes repræsentant, give møde for Europa-Parlamentet med henblik på at drøfte generelle spørgsmål vedrørende Europol. Formanden for Rådet, eller dennes repræsentant, kan lade sig assistere af Europols direktør.

\section{Strafferetligt samarbejde}

Rådet bemyndigede den 26. april 2002 formandskabet til at indlede forhandlinger om en samarbejdsaftale mellem EU og USA vedrørende udlevering og gensidig retshjalp $i$ straffesager. Samarbejdsaftalen vil skulle supplere og lette anvendelsen af de eksisterende bilaterale ordninger mellem USA og EU's medlemsstater med henblik på retsforfølgningen af straffesager vedrørende bl.a. terrorisme.

Under det danske formandskab blev der gjort væsentlige fremskridt i forhandlingerne mellem EU og USA, og på rådsmødet (retlige og indre anliggender) den 19. december 2002 kunne formandskabet således på baggrund af de intensive forhandlinger og adskillige møder med de amerikanske forhandlere præsentere udkast til samarbejdsaftaler mellem EU og USA om henholdsvis udlevering og gensidig retshjælp i straffesager. ${ }^{8}$

På rådsmødet (retlige og indre anliggender) den 19. december 2002 lykkedes det at nå til politisk enighed om en ramme for en samlet kompromisløsning vedrørende et forslag til rammeafgørelse om gensidig anerkendelse og fuldbyrdelse af bødestraffe. ${ }^{9}$ Forslaget, der i vidt omfang bygger på andre tilsvarende ramme- 
afgørelser om gensidig anerkendelse og fuldbyrdelse af strafferetlige afgørelser, skal sikre, at en bødestraf pålagt i én medlemsstat hurtigt og efter enkle procedurer kan fuldbyrdes i anden medlemsstat. Det forventes, at Rådet vil kunne nå til samlet politisk enighed om rammeafgørelsen i løbet af 2003.

Der blev under det danske EU-formandskab ligeledes gjort betydelige fremskridt i forhandlingerne om et tilsvarende forslag til rammeafgørelse om gensidig anerkendelse og fuldbyrdelse af strafferetlige afgørelser om konfiskation, ${ }^{10}$ herunder de dele af rammeafgørelsen der vedrører muligheden for at overføre dele af et konfiskeret udbytte fra en strafbar handling til den medlemsstat, hvor der oprindelig er truffet afgørelse om konfiskation som led i en straffesag ("asset sharing"). Forhandlingerne om rammeafgørelsen forventes afsluttet $\mathrm{i}$ løbet af 2003.

\section{Materiel strafferet}

Rådet vedtog den 19. juli 2002 en rammeafgørelse om bekcempelse af menneskehandel. ${ }^{\prime \prime}$

Rammeafgørelsen forpligter medlemsstaterne til at kriminalisere rekruttering, transport, efterfølgende modtagelse samt overførsel af personer, herunder overførsel af kontrol med disse personer, når dette sker ved brug af magt, tvang eller trusler, herunder bortførelse, bedrageri eller svig, magtmisbrug af autoritet eller udnyttelse af en sårbar stilling, eller betaling med henblik på at opnå tilsagn fra en person, der har kontrol over den pågældende, med henblik på udnyttelse af den pågældende, samt forsøg på og medvirken til sådanne forhold. Ved udnyttelse forstås bl.a. tvangsarbejde, slaveri eller slaverilignende former for udnyttelse af arbejdskraft eller udnyttelse af en andens prostitution eller andre former for seksuel udnyttelse, herunder udnyttelse af den pågældende til pornografi.

Efter rammeafgørelsen er det underordnet, om et offer for menneskehandel har givet samtykke til udnyttelsen, hvis de ovennævnte midler er anvendt, mens det, når ofret er et barn, er underordnet, om der foreligger samtykke, selv i de tilfælde, hvor ingen af de nævnte midler er anvendt. Enhver person under 18 år skal i øvrigt anses for et barn.

Medlemsstaterne skal sikre, at de nævnte lovovertrædelser kan straffes med sanktioner, der er effektive, står i et rimeligt forhold til lovovertrædelsen, har afskrækkende virkning og kan medføre udlevering. Herudover skal medlemsstaterne sikre, at de strafbare forhold er undergivet en strafferamme på mindst 8 års fængsel, når handlingerne er begået af en kriminel organisation, har været til fare for ofrets liv, er begået under anvendelse af grov vold eller har forårsaget særlig alvorlig skade på ofret, eller hvis handlingerne er begået mod en særlig sårbar person. Sidstnævnte udtryk omfatter i det mindste tilfælde, hvor ofret er under den seksuelle lavalder i henhold til national ret. 
Rammeafgørelsen forpligter medlemsstaterne til at sikre, at juridiske personer kan gøres ansvarlige med hensyn til de handlinger, der er beskrevet i rammeafgørelsen, i det omfang handlingerne er begået for at skaffe den juridiske person vinding $o g$ er begået af en person, der handler enten individuelt eller som medlem af et organ under den juridiske person. Endvidere forpligtes medlemsstaterne til at sikre, at juridiske personer også kan straffes i tilfælde, hvor f.eks. utilstrækkelig kontrol eller tilsyn fra den juridiske persons side har gjort det muligt for en person, der er underlagt den juridiske persons myndighed, at begå de nævnte lovovertrædelser. Medlemsstaterne skal overfor juridiske personer kunne iværksætte sanktioner, der er effektive, proportionale og har afskrækkende virkning, herunder bødestraf eller andre sanktioner, som f.eks. udelukkelse fra offentlige ydelser og tilskud og forbud mod at udøve kommerciel virksomhed.

Rammeafgørelsens bestemmelser om straffemyndighed forpligter bl.a. medlemsstaterne til at etablere straffemyndighed, når lovovertrædelsen er begået helt eller delvist på medlemsstatens territorium. Herudover kan en medlemsstat vælge at lade sin straffemyndighed omfatte tilfælde, hvor gerningsmanden er statsborger i den pågældende medlemsstat, eller hvor lovovertrædelsen er begået til fordel for en juridisk person, som har sit hjemsted på den pågældende medlemsstats territorium.

På rådsmødet (retlige og indre anliggender) den 14. oktober 2002 blev der opnået politisk enighed om et forslag til rammeafgørelse om børnepornografi og seksuel udnyttelse af børn. ${ }^{12}$ Formålet med forslaget, der forventes vedtaget $\mathrm{i}$ løbet af 2003, er at sikre effektive og mere ensartede strafferetlige regler i medlemsstaterne med henblik på bekæmpelse af børnepornografi og seksuel udnyttelse af børn.

"Børn" defineres i rammeafgørelsen som enhver person, der er under 18 år. Herudover defineres udtrykket "børnepornografi" som pornografisk materiale, der visuelt afbilleder et barn, der er involveret i seksuelt eksplicit adfærd, herunder pirrende fremstilling af barnets kønsorganer eller pubesområde. Udtrykket "børnepornografi" omfatter ligeledes realistiske billeder af et barn, uanset om barnet er virkeligt eller ej, samt billeder af virkelige personer, der fremstår som børn.

Rammeafgørelsen forpligter medlemsstaterne til at gøre det strafbart at tvinge et barn til prostitution eller til deltagelse i pornografiske optrædender. Medlemsstaterne forpligtes endvidere til at gøre det strafbart at opnå vinding ved eller på anden måde udnytte et barn til prostitution eller deltagelse i pornografiske optrædender. Herudover forpligtes medlemsstaterne til at gøre det strafbart at rekruttere et barn til prostitution eller pornografiske optrædender.

Rammeafgørelsen forpligter desuden medlemsstaterne til at kriminalisere seksuel omgang med børn, når den seksuelle omgang er opnået ved tvang, vold eller trusler, ved betaling som modydelse eller ved misbrug af en anerkendt til- 
lidsposition, myndighed eller indflydelse over barnet.

Efter rammeafgørelsen skal medlemsstaterne ligeledes kriminalisere forsætlig produktion, distribution, transmission, udbud og anden udbredelse af børnepornografi, ligesom medlemsstaterne skal kriminalisere anskaffelse og besiddelse af børnepornografi. Medlemsstaterne kan undlade at kriminalisere børnepornografiske forhold i tilfælde, hvor den person, der fremstår som et barn, faktisk var 18 år eller derover på tidspunktet for afbildningen. Medlemsstaterne kan endvidere undlade at kriminalisere produktion og besiddelse af børnepornografi, når den afbildede person er over den seksuelle lavalder, og det pornografiske materiale produceres og besiddes med afbildedes samtykke og med henblik på privat brug. Desuden kan medlemsstaterne undlade at kriminalisere produktion og besiddelse af "fiktiv børnepornografi", når det pornografiske materiale produceres og besiddes med henblik på privat brug.

Medlemsstaterne skal efter rammeafgørelsen sikre, at de nævnte handlinger kan straffes med effektive, proportionale og afskrækkende sanktioner, der som minimum har en strafferamme på fængsel indtil 1 år. Samtidig skal medlemsstaterne træffe de nødvendige foranstaltninger med henblik på at sikre, at strafferammen for at tvinge et barn til prostitution eller pornografiske optrædender samt for at opnå kønslig omgang med et barn ved tvang, vold eller trusler som minimum er på mellem $5 \mathrm{og} 10$ års fængsel.

Herudover skal medlemsstaterne sikre, at strafferammen for at profitere, rekruttere eller på anden måde udnytte et barn til prostitution som minimum er fængsel mellem 5 og 10 år, når,der foreligger skærpende omstændigheder. Efter rammeafgørelsen skal det anses for en skærpende omstændighed, at barnet er under den seksuelle lavalder, at gerningsmanden forsætligt eller ved grov uagtsomhed har bragt barnets liv i fare, at handlingen har indebåret alvorlig vold eller har forårsaget alvorlig skade på barnet, eller at handlingen er begået inden for rammerne af kriminel organisation.

Endelig skal medlemsstaterne sikre en strafferamme på mellem 5 og 10 års fængsel for profitering og rekruttering af et barn til pornografiske optrædender samt for at opnå kønslig omgang med et barn ved betaling som modydelse eller ved misbrug af en anerkendt tillidsposition, myndighed eller indflydelse over barnet, og for bl.a. at producere, distribuere og udbyde børnepornografi, hvis barnet er under den seksuelle lavalder, og de pågældende handlinger er begået under én af de øvrige ovennævnte skærpende omstændigheder.

Rammeafgørelsens bestemmelser om juridiske personers ansvar svarer til reglerne i rammeafgørelsen om menneskehandel, jf. ovenfor.

Medlemsstaterne er efter rammeafgørelsen forpligtede til at etablere straffemyndighed, når lovovertrædelsen er begået helt eller delvist på medlemsstatens territorium. For så vidt angår børnepornografi fremgår det af rammeafgørelsen, at en lovovertrædelse begået ved hjælp af et edb-system skal anses for at være begået på territoriet i den medlemsstat, hvorfra lovovertræderen har opnået 
adgang til edb-systemet, uanset om selve edb-systemet befinder sig i denne medlemsstat.

Grov seksuel udnyttelse af børn skal i øvrigt efter rammeafgørelsen kunne retsforfølges efter, at ofret har nået myndighedsalderen

Den 28. november 2002 vedtog Rådet en rammeafgørelse om menneskesmugling. ${ }^{13}$

Efter rammeafgørelsen skal medlemsstaterne træffe de nødvendige foranstaltninger for sikre, at de strafbare handlinger, der fremgår af Rådets direktiv $2002 / 90 / \mathrm{EF}^{14}$ af samme dato om hjælp til ulovlig indrejse og transit samt ulovligt ophold, kan straffes med strafferetlige sanktioner, der er effektive, står i et rimeligt forhold til lovovertrædelsen, har afskrækkende virkning, kan medføre udlevering og eventuelt andre foranstaltninger, herunder f.eks. konfiskation af det transportmiddel, der er benyttet i forbindelse med den strafbare handling, forbud mod direkte eller gennem en mellemmand at udøve sådan erhvervsmæssig virksomhed, hvorunder den strafbare handling blev begået, og udvisning med indrejseforbud, hvis den dømte person ikke er statsborger i en medlemsstat.

Ifølge direktivet skal medlemsstaterne gennemføre passende sanktioner over for enhver, der hjælper eller forsøger at hjælpe en udlænding, der ikke er statsborger i en medlemsstat, med at rejse til eller igennem en medlemsstats område og derved overtræde den pågældende stats lovgivning vedrørende udlændinges indrejse eller gennemrejse. Medlemsstaterne skal endvidere gennemføre passende sanktioner over for enhver, der med vinding for øje hjælper eller forsøger at hjælpe en udlænding, som ikke er statsborger i en medlemsstat, med at opholde sig på en medlemsstats område og derved overtræde den pågældende stats lovgivning vedrørende udlændinges ophold. Medvirken til de nævnte handlinger skal ligeledes kunne straffes. Enhver medlemsstat kan ifølge direktivet beslutte, at den ikke vil gennemføre sanktioner over for den nævnte adfærd i tilfælde, hvor formålet med adfærden har været at yde humanitær hjælp til den pågældende udlænding.

Ifølge rammeafgørelsen skal bistand til ulovlig indrejse eller gennemrejse være undergivet en strafferamme på mindst 8 års fængsel, når bistanden ydes $\mathrm{i}$ berigelsesøjemed samt af en kriminel organisation eller på en sådan måde, at den er til fare for den person, der smugles. Hvis det er nødvendigt for at sikre sammenhængen i den nationale straffelovgivning, kan strafferammen dog fastsættes til 6 års fængsel, forudsat at denne strafferamme er mellem de strengeste straffe i national ret for sammenlignelige lovovertrædelser.

Rammeafgørelsens bestemmelser om juridiske personer ansvar svarer til reglerne i rammeafgørelsen om menneskehandel, jf. ovenfor.

Efter rammeafgørelsens bestemmelser om straffemyndighed er en medlemsstat forpligtet til at have straffemyndighed, hvis en lovovertrædelser omfattet af rammeafgørelsen er begået helt eller delvist på medlemsstatens territorium. 
Endvidere kan en medlemsstat etablere straffemyndighed i tilfælde, hvor gerningsmanden er statsborger i den pågældende medlemsstat, eller hvor lovovertrædelsen er begået med henblik på en juridisk persons vinding, og denne juridiske person har hjemsted på medlemsstatens territorium. En medlemsstat, der ikke udleverer egne statsborgere, skal træffe de nødvendige foranstaltninger med henblik på at sikre, at medlemsstaten har straffemyndighed i tilfælde, hvor de strafbare handlinger bliver begået af en af dens egne statsborgere uden for den pågældende medlemsstats territorium.

I forbindelse med rådsmødet (retlige og indre anliggender) den 19. december 2002 blev der konstateret politisk enighed om et forslag til rammeafgørelse om alvorlig miljøkriminalitet. ${ }^{15}$

Rammeafgørelsen, der forventes vedtaget i løbet af 2003, tager sigte på at sikre effektive og mere ensartede strafferetlige regler i medlemsstaterne for så vidt angår alvorlig miljøkriminalitet.

Efter rammeafgørelse forpligtes medlemslandene til at sikre, at forsætlig udledning, emission eller tilførsel af et kvantum stoffer eller af ioniserende stråling i luft, jord eller vand, der forårsager dødsfald eller alvorlig personskade, er strafbar.

Herudover forpligtes medlemslandene til at kriminalisere en række nærmere opregnede miljøforbrydelser af alvorlig karakter, når de i øvrigt begås forsætligt.

Forsøg, medvirken samt groft uagtsomme forhold i forbindelse med disse handlinger skal ligeledes kunne straffes, ligesom medlemsstaterne skal sikre sanktioner, der er effektive, står i et rimeligt forhold til overtrædelsen og har afskrækkende virkning, herunder - i det mindste i de groveste tilfælde - frihedsstraf, som kan medføre udlevering.

Rammeafgørelsen indeholder herudover bestemmelser og juridiske personers ansvar, der svarer til reglerne i rammeafgørelsen om menneskehandel, jf. ovenfor.

Efter rammeafgørelsens bestemmelser om jurisdiktionskompetence forpligtes hver medlemsstat til at have straffemyndighed, når handlingen er begået helt eller delvist på den pågældende medlemsstats område, uanset om virkningerne af overtrædelsen gør sig gældende et andet sted end på medlemsstatens territorium. Herudover forpligtes medlemsstaterne til at have straffemyndighed, når lovovertrædelsen er begået på skibe eller luftfartøjer, der fører medlemstatens flag. Medlemsstater, som i henhold til national ret ikke udleverer egne statsborgere, skal ifølge rammeafgørelsen træffe de nødvendige foranstaltninger for at fastlægge straffemyndighed med hensyn til alvorlig miljøkriminalitet begået af egne statsborgere uden for territoriet.

På rådsmødet (retlige og indre anliggender) den 19. december 2002 blev der ligeledes opnået politisk enighed om et forslag til rammeafgørelse vedrørende bestikkelse $i$ den private sektor. ${ }^{16}$ Formålet med forslaget, der forventes vedtaget 
i løbet af 2003, er at sikre effektive og mere ensartede strafferetlige regler i medlemsstaterne med henblik på bekæmpelse af bestikkelse i den private sektor.

Rammeafgørelsen forpligter medlemsstaterne til at kriminalisere aktiv og passiv bestikkelse i den private sektor samt medvirken hertil. For så vidt angår aktiv bestikkelse forpligtes medlemsstaterne til at kriminalisere forsætlig adfærd, der består i direkte eller gennem tredjemand at love, tilbyde eller yde en person, der i hvilken som helst egenskab leder eller arbejder for en virksomhed i den private sektor, en uberettiget fordel, uanset dennes art, for vedkommende selv eller for tredjemand, for at denne person i strid med sine pligter skal udføre eller undlade at udføre en handling. For så vidt angår passiv bestikkelse forpligtes medlemsstaterne til at kriminalisere forsætlig adfærd, der består i direkte eller gennem tredjemand at anmode om eller modtage en uberettiget fordel, uanset dennes art, for sig selv eller tredjemand samt at tage imod et løfte herom, hvis man i en hvilken som helst egenskab leder eller arbejder for en virksomhed i den private sektor, for i strid med ens pligter at udføre eller undlade at udføre en handling. Både i relation til aktiv og passiv bestikkelse er det en forudsætning, at adfærden udøves som led i forretningsmæssige aktiviteter. Herudover gælder rammeafgørelsens bestemmelser for forretningsmæssige aktiviteter både i profitorienterede og ikke-profitorienterede virksomheder. Medlemsstaterne kan ved tidsbegrænsede erklæringer indskrænke kriminaliseringsforpligtelsen til adfærd, som involverer eller kunne involvere konkurrence forvridning i forbindelse med erhvervelse af varer eller kommercielle tjenesteydelser.

Efter rammeafgørelsen skal medlemsstaterne sikre, at de nævnte handlinger er undergivet effektive, proportionale og afskrækkende sanktioner, herunder som minimum i form af en strafferamme på fængsel mellem 1 og 3 år. Herudover skal der kunne træffes afgørelse om rettighedsfrakendelse i forbindelse med en dom for bestikkelse i den private sektor, hvis det udviste forhold begrunder en nærliggende fare for misbrug af den pågældendes stilling eller hverv.

Rammeafgørelsens bestemmelser om juridiske personers ansvar svarer til reglerne i rammeafgørelsen om menneskehandel, jf. ovenfor.

Rammeafgørelsens bestemmelser om jurisdiktionskompetence forpligter bl.a. medlemsstaterne til at etablere straffemyndighed, når lovovertrædelsen er begået helt eller delvist på medlemsstatens territorium.

Endelig blev der på rådsmødet (retlige og indre anliggender) den 19. december 2002 opnået politisk enighed om et forslag til rammeafgørelse om konfiskation af udbytte, redskaber og formuegoder i forbindelse med strafbart forhold. ${ }^{17}$

Formålet med forslaget, der forventes vedtaget i løbet af 2003, er at sikre effektive og mere ensartede konfiskationsregler i medlemsstaterne, herunder om udvidet konfiskation, bl.a. som led i samarbejdet om fuldbyrdelse af konfiskationsafgørelser truffet $\mathrm{i}$ en anden medlemstat.

Rammeafgørelsen forpligter medlemsstaterne til at sikre, at det er muligt helt eller delvist at konfiskere redskaber og udbytte, der stammer fra lovovertrædel- 
ser, der kan straffes med frihedsstraf af mere end 1 års varighed, eller formuegoder, hvis værdi svarer til en sådant udbytte.

Herudover skal medlemsstaterne træffe de nødvendige foranstaltninger med henblik på at sikre, at der kan ske hel eller delvis konfiskation af formuegoder, der tilhører en person, som findes skyldig i en kriminel handling, der er begået inden for rammerne af en kriminel organisation, hvis den kriminelle handling er omfattet af en række nærmere opregnede rammeafgørelser vedtaget af Rådet med henblik på en indbyrdes tilnærmelse af medlemsstaternes strafferetlige regler. Det er ligeledes en forudsætning, at handlingen er undergivet en strafferamme på mindst 5 års fængsel, og at handlingen er af en sådan karakter, at den kan give betydeligt udbytte. Konfiskation skal i det mindste kunne ske i tilfælde, hvor en national domstol på grundlag af konkrete forhold er overbevist om, at det pågældende formuegode stammer fra kriminelle handlinger foretaget af den dømte person.

\section{Forebyggelse og bekæmpelse af grænseoverskridende kriminalitet}

\section{Organiseret kriminalitet}

På et ministermøde mellem EU-landene og kandidatlandene den 14. oktober 2002 vedtog justits- og indenrigsministrene en falles erklcering om beskyttelse af eksportchauffører mod at blive ofre for organiseret kriminalitet.

I den fælles erklæring fastslår medlemslandene og kandidatlandene deres vilje til at iværksætte nationale undersøgelser af antallet af overfald på eksportchauffører og foretage analyser af problemets karakter, omfang og baggrund i deres respektive lande.

Erklæringen lægger desuden op til en styrkelse af sikkerheden på udsatte transportruter, en lettere adgang til information om sikre rastepladser samt en forbedring af støtten til transportchauffører, der har været udsat for voldelige overfald.

\section{Krigsforbrydelser m.v.}

På rådsmødet (retlige og indre anliggender) den 14. oktober 2002 blev der opnået politisk enighed om en rådsafgørelse vedrørende efterforskning af krigsforbrydelser, folkedrab og forbrydelser mod menneskeheden. ${ }^{18}$

Formålet med forslaget, der forventes vedtaget i løbet af 2003, er at øge medlemsstaternes muligheder for at efterforske og retsforfølge personer, der har deltaget $\mathrm{i}$ eller fremmet udførelsen af krigsforbrydelser m.v.

Rådsafgørelsen forpligter medlemsstaterne til at sikre, at de retshåndhævende myndigheder i fornødent omfang inddrages i udlændingemyndighedernes sagsbehandling. Udlændingemyndighederne skal således orientere de retshåndhævende myndigheder, når der i forbindelse med behandlingen af en ansøgning om opholdstilladelse konstateres forhold, som giver anledning til mistanke om, 
at ansøgeren har begået krigsforbrydelser, folkedrab eller forbrydelser mod menneskeheden, der kan medføre strafforfølgning i en medlemsstat eller ved en international domstol. Medlemsstaterne skal i den forbindelse tilvejebringe det fornødne grundlag for udvekslingen af oplysninger mellem udlændingemyndighederne og de retshåndhævende myndigheder.

Hvis der er mistanke om, at en udlænding, der søger om opholdstilladelse, har været involveret i krigsforbrydelser, folkedrab eller forbrydelser mod menneskeheden, skal medlemsstaterne ifølge rådsafgørelsen sikre, at sagen efterforskes og retsforfølges i overensstemmelse med national ret. Medlemsstaterne skal i den forbindelse ligeledes yde hinanden den fornødne bistand i overensstemmelse med national ret og internationale aftaler, herunder efter omstændighederne ved at videregive oplysninger, der tidligere er afgivet overfor udlændingemyndighederne $i$ en anden medlemsstat.

Bliver de retshåndhævende myndigheder i en medlemsstat opmærksomme på, at en person, som mistænkes for krigsforbrydelser, folkedrab eller forbrydelser mod menneskeheden, opholder sig $i$ en anden medlemsstat, skal de underrette de relevante myndigheder i den pågældende medlemsstat herom.

Ifølge rådsafgørelsen skal medlemsstaterne i øvrigt overveje behovet for at etablere eller udpege specialiserede enheder, der særligt har til opgave at forestå efterforskningen og retsforfølgningen af sager vedrørende krigsforbrydelser, folkedrab og forbrydelser mod menneskeheden, ligesom medlemsstaterne skal udpege nationale koordinatorer på dette område, som skal mødes med regelmæssige mellemrum.

\section{Narkotikakriminalitet}

Kommissionen fremlagde den 6. november 2002 en midtvejs-evaluering af $E U$ 's narkotikastrategi og narkotikahandlingsplan for 2000-2004. På baggrund af midtvejs-evalueringen fastlagde Rådet den 28. november 2002 en række politiske prioriteter og retningslinjer for den fortsatte gennemførelse af EU's narkotikastrategi og narkotikahandlingsplan, som efterfølgende blev godkendt på Det Europæiske Råds møde i København den 12.-13. december 2002.

Den 28. november 2002 godkendte Rådet ligeledes en sarlig handlingsplan for gennemførelsen af initiativer med henblik på bekcempelse af syntetisk narkotika, ligesom der ved samme lejlighed blev opnået politisk enighed om en henstilling vedrørende behandlingen af stofmisbrugere i fangsler $m . v \cdot{ }^{19} \mathrm{I}$ henstillingen opfordres medlemsstaterne til at iværksætte en række tiltag med henblik på at styrke den behandlingsmæssige indsats over for stofmisbrugere i fængsler m.v.

\section{Terrorisme}

Rådet vedtog den 28. november 2002 en afgørelse om evaluering af medlemsstaternes indsats som led i bekæmpelsen af terrorisme. ${ }^{20}$

Rådsafgørelsen indebærer, at der sammensættes en række evalueringshold 
bestående af to nationale eksperter, der ikke må være statsborgere i den medlemsstat, som holdet skal evaluere. Evalueringsholdene, der bistås af Kommissionen og Rådssekretariatet, skal på baggrund af medlemsstaternes besvarelse af spørgeskemaer og eventuelle evalueringsbesøg i de enkelte medlemsstater udarbejde evalueringsrapporter vedrørende de nationale foranstaltninger til bekæmpelse af terrorisme, som har betydning for medlemsstaternes internationale samarbejde på området.

Når en evalueringsrunde er afsluttet, orienteres Rådet om resultatet af evalueringerne. Rådet kan på denne baggrund rette henstillinger til de enkelte medlemsstater. Ved afslutningen af en evalueringsrunde orienteres Europa-Parlamentet ligeledes om evalueringens resultater. Første evalueringsrunde skal være gennemført medio 2003.

Rådet vedtog den 19. december 2002 en afgørelse om det politimcessige og strafferetlige samarbejde med henblik på bekampelse af terrorisme. ${ }^{21}$

Rådsafgørelsen finder anvendelse i forhold til efterforskningen og retsforfølgningen af terrorhandlinger, der er omfattet af Rådets rammeafgørelse af 13 . juni 2002 om bekæmpelse af terrorisme ${ }^{22}$, og som har tilknytning til de personer, grupper og enheder, der er opført i bilaget til Rådets fælles holdning 2001/931/FUSP om anvendelse af specifikke foranstaltninger til bekæmpelse af terrorisme ${ }^{23}$.

Ifølge rådsafgørelsen skal hver medlemsstat udpege en enhed inden for politiet, der - i overensstemmelse med national ret - skal have adgang til og indsamle oplysninger fra politiets efterforskning af relevante terrorhandlinger. Oplysninger med henblik på identifikation af personer, grupper eller enheder, oplysninger om de handlinger, der efterforskes, og de særlige omstændigheder, hvorunder de har fundet sted, oplysninger om forbindelse til andre relevante tilfælde af terrorhandlinger, oplysninger om anvendelse af kommunikationsteknologi samt oplysninger om trusler knyttet til besiddelse af masseødelæggelsesvåben videregives i videst muligt omfang til Europol i overensstemmelse med Europolkonventionen og national ret.

Tilsvarende udpeger hver medlemsstat en eller flere judicielle myndigheder, der skal have adgang til og mulighed for at indsamle alle oplysninger inden for den judicielle myndigheds ansvarsområde for så vidt angår relevante terrorhandlinger. Oplysninger med henblik på identifikation af personer, grupper og enheder, oplysninger om de handlinger, der efterforskes, og de særlige omstændigheder, hvorunder de har fundet sted, oplysninger om forbindelse til andre relevante tilfælde af terrorhandlinger samt oplysninger om gensidig retshjælp, herunder retsanmodninger, der måtte være rettet til eller fremsat af en anden medlemsstat, samt udfaldet heraf, videregives i videst muligt omfang til Eurojust i overensstemmelse med rådsafgørelsen om oprettelsen af Eurojust og national ret.

Medlemsstaterne skal ifølge rådsafgørelsen sikre, at alle relevante oplysninger, som videregives til Europol eller Eurojust, og som vedrører enten nævnte 
personer, grupper eller enheder, eller handlinger, som disse formodes at have begået eller at ville begå, kan udveksles mellem Europol og Eurojust i overensstemmelse med en kommende samarbejdsaftale mellem Europol og Eurojust.

Herudover skal medlemsstaterne træffe de nødvendige foranstaltninger for at sikre, at anmodninger om gensidig retshjælp og om anerkendelse og fuldbyrdelse af retsafgørelser, der fremsættes af en anden medlemsstat i forbindelse med terrorhandlinger omfattet af rådsafgørelsen, behandles som hastesager med høj prioritet.

Endelig skal medlemsstaterne træffe de nødvendige foranstaltninger for at sikre, at relevante oplysninger kan gøres tilgængelige eller stilles til rådighed for andre medlemsstaters myndigheder i overensstemmelse med national ret og relevante internationale regler, når der i disse medlemsstater gennemføres eller indledes efterforskning eller retsforfølgning omfattet af rådsafgørelsen.

\section{Schengen-samarbejdet}

På et møde på ministerniveau den 19. december 2002 mellem EU-landene og Norge og Island, der er associerede deltagere i Schengen-samarbejdet om ophævelse af personkontrollen ved de indre grænser m.v., blev der opnået enighed om en række retningslinjer for kandidatlandenes fulde gennemforelse og anvendelse af Schengen-reglerne efter deres indtraden i Den Europaiske Union.

Det fremgår af disse retningslinjer, at Schengen-reglernes fulde iværksættelse $i$ forhold til nye medlemsstater forudsætter en forudgående evaluering og kontrol af, at alle forudsætninger er opfyldt. Det betyder, at de nye medlemsstater skal dokumentere, at de er i stand til at opfylde de relevante krav i Schengenreglerne på en ensartet, korrekt, sammenhængende og effektiv måde.

En særlig arbejdsgruppe under Rådet vil fastlægge, hvilke kriterier og krav, herunder hvilke krav vedrørende kontrollen ved de ydre grænser, der skal være opfyldt, for at personkontrollen ved de indre grænser kan ophæves. Disse kriterier og krav fastsættes konkret og under hensyn til de særlige forhold, der gør sig gældende for hver enkelt medlemsstat. På baggrund af spørgeskemaundersøgelser og kontrolbesøg i de nye medlemsstater vil evalueringsrapporter om de enkelte lande blive forelagt for Rådet, og det er herefter op til Rådet at træffe afgørelse om Schengen-reglernes gennemførelse og anvendelse i forhold til hver af de nye medlemsstater på den eller de datoer, som Rådet finder passende.

\section{Afslutning}

Det danske formandskab lagde på det politimæssige og strafferetlige område afgørende vægt på at videreføre det arbejde, der var iværksat af tidligere formandskaber. Det lykkedes i den forbindelse at få vedtaget eller i den mindste afsluttet forhandlingerne om en række konkrete forslag, som gennem længere tid har været behandlet i Rådet.

Herudover fremlagde Danmark i begyndelsen af formandskabet 12 nye for- 
slag på det politimæssige og strafferetlige område, og i løbet af mindre end seks måneder blev forhandlingerne om $10 \mathrm{af}$ disse nye initiativer afsluttet.

På den baggrund må resultaterne af formandskabet på det politimæssige og strafferetlige område betegnes som yderst tilfredsstillende, hvilket bl.a. må tilskrives en målrettet og resultatorienteret indsats på alle niveauer under formandskabet samt ikke mindst et omfattende og langvarigt forberedende arbejde forud for formandskabet.

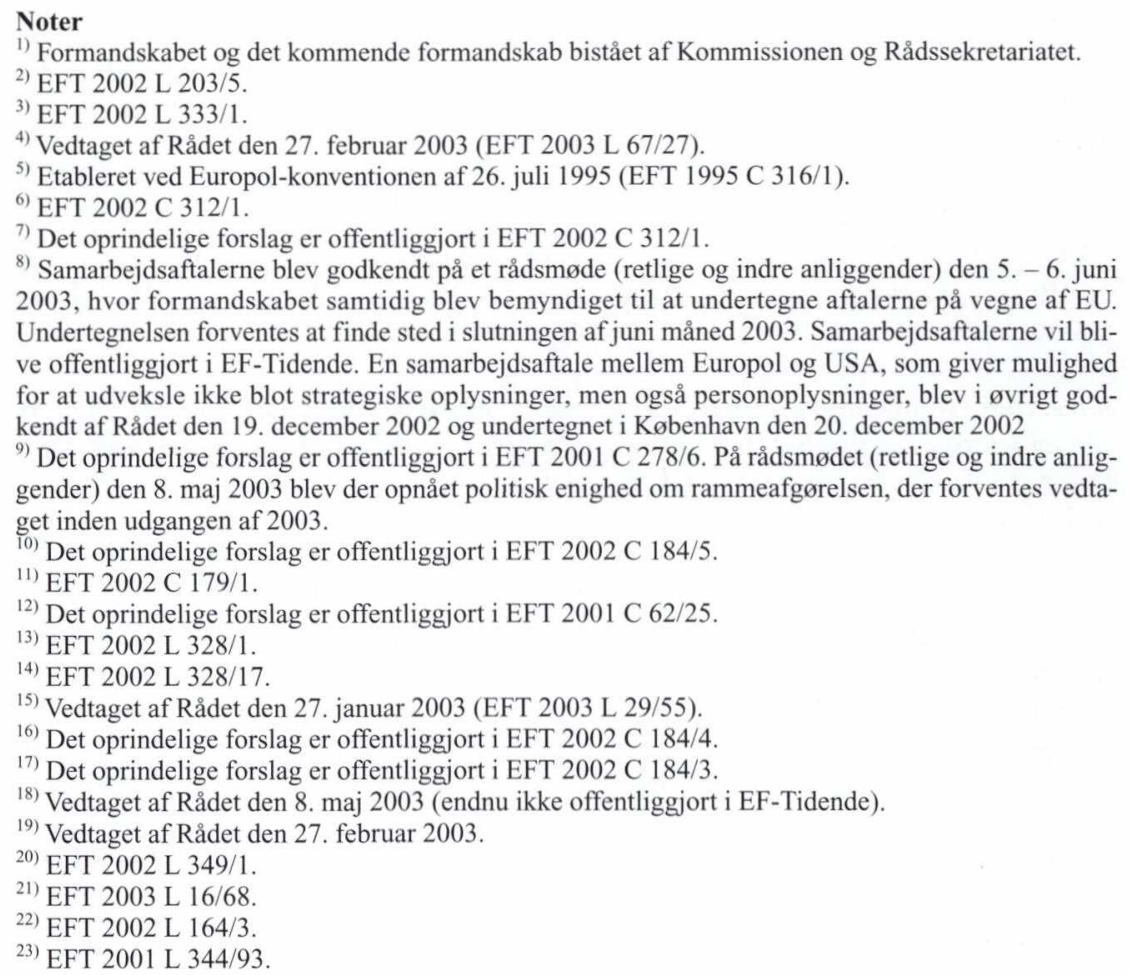

Adresse: Rigspolitiet, afd. A

Polititorvet 14

DK - 1780 København V. 